\title{
ART STUDIES IN THE CONTEXT OF POWER RELATIONS IN LITHUANIA, 1940-1953: THE CASE OF THE ACTIVITIES AND CLOSURE OF KAUNAS APPLIED AND DECORATIVE ART INSTITUTE
}

Summary. The main purpose of this report is to discuss the influence of political power on art studies in Lithuania and the creative work of artists from 1940 to 1953. It will be based on the destruction of the Kaunas Institute of Applied and Decorative Arts, which is little known to art historians. After the Second World War, this institute actually followed the traditions of Kaunas Art School (1922-1940): that was the reason for its closure in 1951. The closure was officially called the reorganisation and continuation of art studies in Vilnius.

The post-war ideological content and power of the government acted in the study process. However, in essence, educators were guided by their modernist attitudes and did not accept Soviet directives. The report will try to show how political power has corrected art studies and changed the work of mature artists.

This article raises a question about the cost of adaptation and resistance in life and creation. The idea is that the destruction of an art institution is possible, but it is impossible to completely destroy the art school tradition. These and other similar issues will be addressed in the article, based on archival documents and examples of works by several different generations of artists - Vytautas Kairiūkštis (1891-1961), Liudas Truikys (1904-1987), Zenonas Varnauskas (1923-2010).

Keywords: Kaunas Art School, Kaunas Applied and Decorative Art Institute, World war II, national modernism, socialist realism.

\section{INTRODUCTION}

The collision of two totalitarian systems in the period between 1939 and 1945 brought painful consequences for Europe. In 1940, Lithuania was occupied by the Soviet Union, and its culture found itself in the position of a colonised subaltern. ${ }^{1}$ The dictate of the ruling establishment determined the politicisation of all fields of culture, the confusion of creators and the atmosphere of distrust.

The relations between art and politics in the 20th century have received considerable research attention. In writing this article, the author referred to the research conducted by Giedrè Jankevičiūte, Lijana Natalevičienè, Boris Groys and Piotr Piotrowski. ${ }^{2}$ Until today, art researchers have showed less interest in the effect that the political shift and the forced change of regime had on the process of art studies, artists-teachers and students, the nature of relations that were formed between them, and the stance that they chose.

The aim of this article is to discuss the impact of political power on art studies in Lithuania in the period between 1940 and 1951. The main object of research is the Kaunas Institute of Applied Art and the history of its annihilation. A look at the transformations and destruction of this institute could be useful for art researchers trying to find answers to the questions about artists' adjustment or resistance in the Soviet period. ${ }^{3}$

Due to the limited length of the article, the most attention is given to the teachers and students of the Textile Department of the Institute of Applied Art, which was the former Kaunas Art School ${ }^{4}$ (Fig. 1) that operated between 1922 and 1940. When the Soviets returned the Vilnius region to Lithuania (1939), it was decided to transfer part of the art 


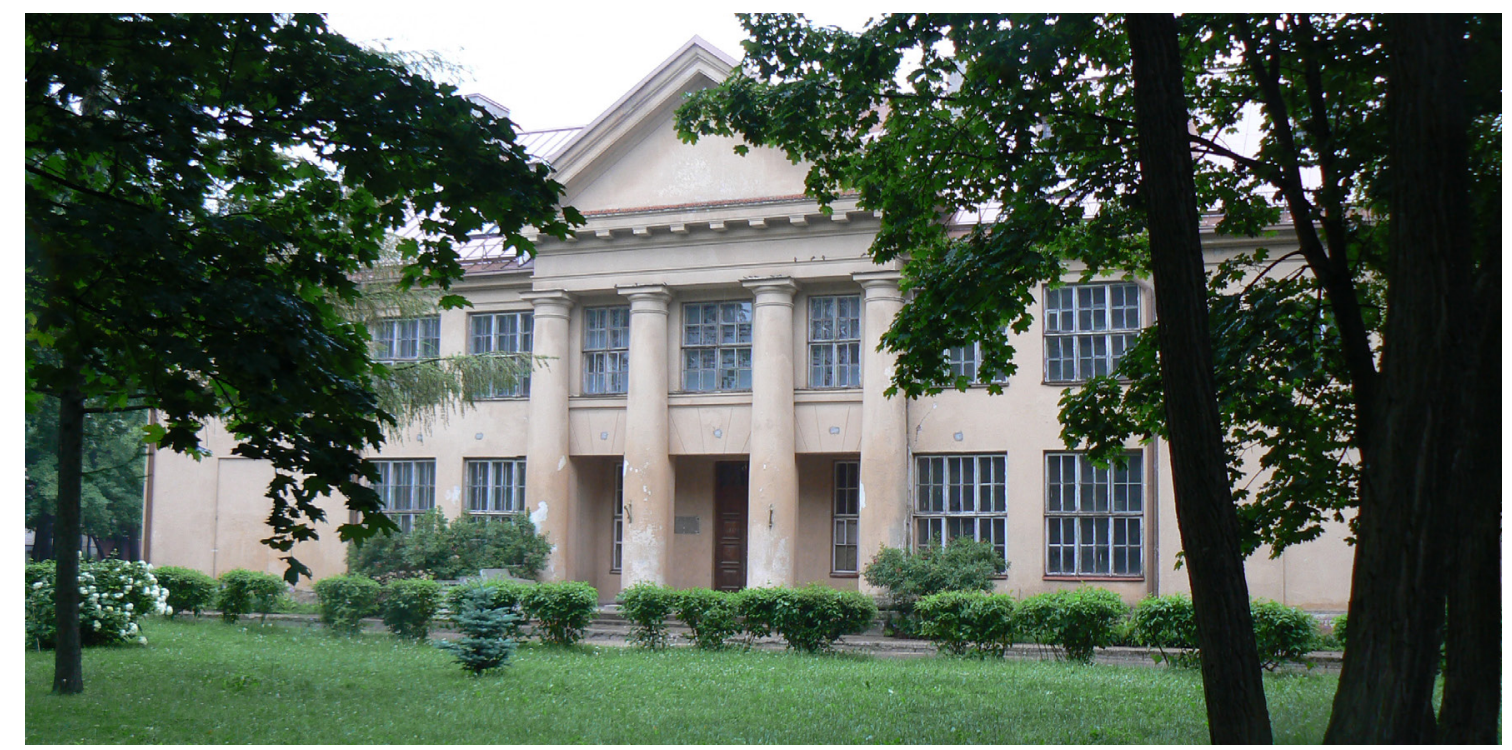

Fig. 1. Kaunas Art School. 1922. Architect Vladimiras Dubeneckis. The school operated from 1922 to 1940. After the Soviet occupation of Lithuania, this building housed the Institute of Applied Art (1940-1951). Photo by Rasa Žukiene, 2016

studies to Vilnius. The Kaunas Art School and the Art Faculty of Stephen Báthory University were restructured $^{5}$ into two higher art schools: the Vilnius School of Free Arts and the Kaunas School of Applied Art. A year later, when Lithuania was occupied by the Soviets, the latter was renamed as the Institute of Applied Art, and the Vilnius School of Free Arts became the Vilnius Academy of Arts. ${ }^{6}$ Yet the matter did not rest there. In the postwar period, both schools were merged to become the State Art Institute of the Lithuanian SSR (1951). The name of the Kaunas Art School remained in the history of art.

\section{CREEPING SOVIETISATION AND \\ MANIFESTATION OF POLITICAL POWER}

The Soviet regime showed its power in all fields of life. Already in June 1940, tuition fees were introduced for young people of a richer background. Students had to fill out questionnaires about the material situation of their parents. ${ }^{7}$ In the summer of 1940, some strangers not speaking Lithuanian and not having any drawing skills showed up at the entrance examinations to the Kaunas Institute of Applied Art. The institute's director Liudvikas Strolis addressed the Commissar for People's Education of the Lithuanian SSR, Antanas Venclova, regarding this unexpected problem. The latter's reply was brief: if they came to live in Lithuania, they could study. Another group of candidates claimed in their applications that the previous regime was an obstacle for them to get into that art school. ${ }^{8}$ This was certainly untrue, as before the war, people of various nationalities studied at the Kaunas Art School. ${ }^{9}$ There were even more signs of creeping Sovietisation. For example, until September 1940, all Lithuanian symbols, historical paintings and portraits of persons whose views did not comply with the idea of building a socialist Lithuania had to be removed; singing the Lithuanian national anthem and praying, a customary part of festive rituals in Lithuanian schools before the war, was also forbidden at the Institute. ${ }^{10}$

These facts of Sovietisation, just like arbitrary Soviet administration, in 1940, still had little impact on art studies. Their general direction and methods of teaching did not radically change. Repressive administration of studies started after the war, when the Soviets returned. But already in the autumn of 1940, students and teachers had to attend ideological lectures, at that time called "the subject of consciousness-raising", at the institute. They were taught three hours a week by a printmaker with leftist views, Vytautas Jurkūnas. Teachers had to find ways to demonstrate their loyalty to the new political regime. A deplorable document of 15 February 1941 has survived $^{11}$ - a teachers' pledge ${ }^{12}$ to set up Lenin's corner at the institute. In the document, the duties of all the teachers were laid down in great detail. For example, Vytautas Jurkūnas and Vytautas Kasiulis were placed in charge of writing "a text suitable for Lenin's corner", Stasys Ušinskas had to make stained glass, Jonas 
Prapuolenis had to make furniture, Juozas Talmantas had to provide books, newspapers, portraits and chess, and Rimtas Kalpokas had to take care of painting the floor. ${ }^{13}$ Failure to implement the project was out of the question - repressions and interrogations were a usual occurrence.

In the spring of 1941, the institute's director, Liudvikas Strolis, issued an order to save electricity, to stop heating stoves twice a day, not to stay overnight on the institute's premises and not to consume alcoholic drinks. ${ }^{14}$ It was obvious that with the war going on, people were plagued by uncertainty and fear. ${ }^{15}$ In the summer of 1944, the front was approaching from the east, and people were fleeing en masse from Lithuania. ${ }^{16}$ At the start of the school year, none of the prominent teachers - Vytautas Kazimieras Jonynas, Adomas Galdikas, Mstislavas Dobužinskis, Vytautas Kašuba, Antanas Tamošaitis and Viktoras Petravičius - remained at the institute.

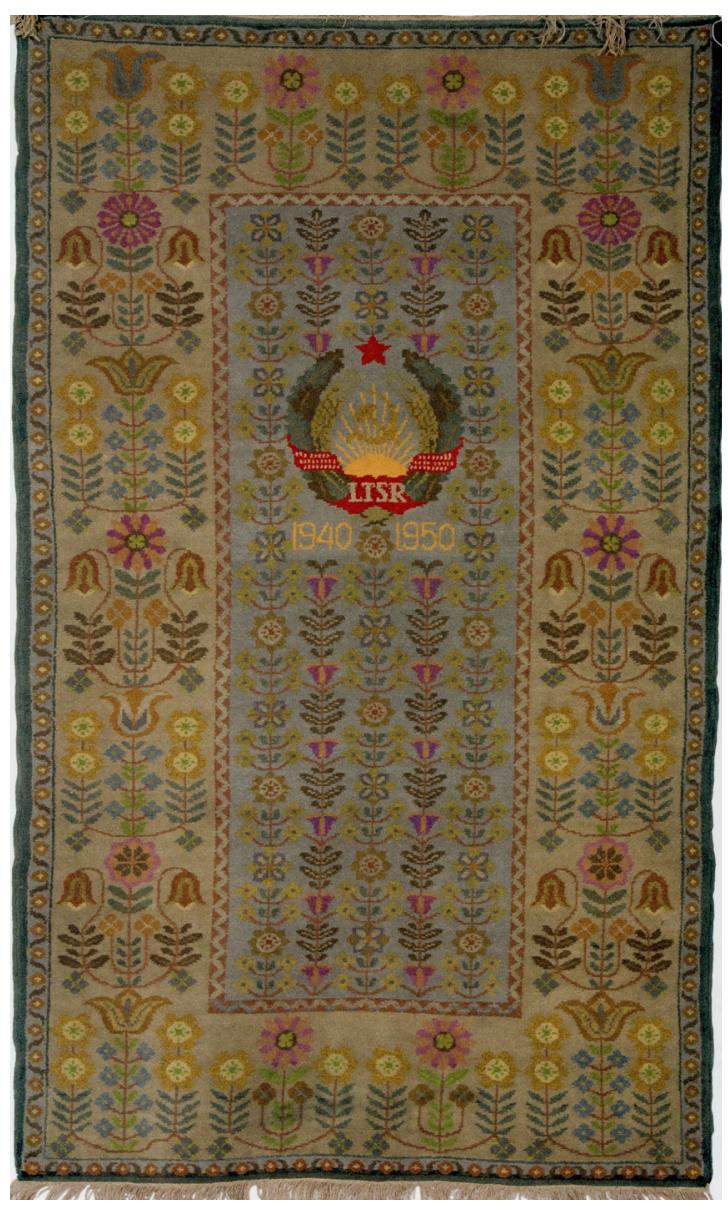

Fig. 2. Gražina Martinkevičiūtè. The Emblem of the Soviet Socialist Republic of Lithuania 1940-1950. 1950. Wool, linen, knotting technique, $226 \times 132 \mathrm{~cm}$. Lithuanian National Museum of Art
In order to start the teaching process, not only did the workload of those who had retreated to the West have to be distributed, but also an adequate behaviour strategy had to be chosen - not to stand out and not to attract the attention of the institute's ideological staff. In the postwar period, teachers had to bear the brunt of the Soviet "reforms". These reforms were intended to destroy the independence of the higher school, forcibly introduce the method of Socialist Realism and make everyone forget Western culture as quickly as possible, as the majority of teachers were graduates of European art schools. A programme of Socialist Realism and Marxist education centrally prepared in Moscow was suddenly imposed on both the teachers and students. Under the conditions of political hegemony and strict censorship, Soviet ideology and Socialist Realism became an obligatory and only choice. ${ }^{17}$ (Fig. 2)

\section{POLITICAL POWER AND TEATCHER'S STANCE}

"It is only in the framework of a socialist government that art becomes a full-fledged cultural factor, all the more that occasional inferior art or a wrong direction is eliminated by means of criticism, public discussion or by the government's measures", ${ }^{18}$ wrote the young teacher Rimtas Kalpokas in his lecture notes. Today, it is almost impossible to establish if the teachers really believed in what they said publicly. Archival documents show the absurd obedience, naïve or fake, of artists-teachers. Was it possible in the conditions of the totalitarian regime not to accept the Soviet rules? What choice did they have - to become cogs in the propaganda machine, or merely imitate the obligatory social behaviour? In the postwar period, each teacher and student faced these questions. Opportunism and timeserving quickly took root in the institute. The general atmosphere both at the institute and the city of Kaunas became intellectually poor and was accompanied by moral discomfort and natural fear about the future.

This situation is vividly illustrated by the articles of the artist and teacher Vytautas Kairiūkštis in the press. In the interwar period, he kept contacts with Polish, Russian and Italian avant-garde creators. ${ }^{19}$ In his postwar texts, he expressed a distinct approval of the Socialist Realism doctrine, ${ }^{20}$ and 
showed admiration for Soviet artistic life, ${ }^{21}$ part of which was his workplace - the Institute of Applied and Decorative Art. Kairiūkštis taught universal history of art and composition. His lectures were popular with students. When talking about the art of Ancient Egypt, the Renaissance or Baroque, he explained the structure of a painting, the relations of figures, the effect of colour patches and lines, and the interaction of colours and moods. This manner of teaching did not appeal to art functionaries. They required teaching an extensive history of Soviet art, focusing on the post-revolutionary period, and explaining the advantages of Socialist Realism to the students. Kairiūkštis, a direct witness of postrevolutionary manifestations of the avant-garde in Moscow, ${ }^{22}$ did not change his position, and did not impose Socialist Realism on his students, even though, as we saw, he praised it in the press. It was a typical attempt to manoeuvre in order to survive. However, in the summer of 1950, Kairiūkštis was fired from the institute. ${ }^{23}$ The artist took it as political lynching. He wrote in a letter to a friend of his youth: "during the last 'purge' [...] very unexpectedly

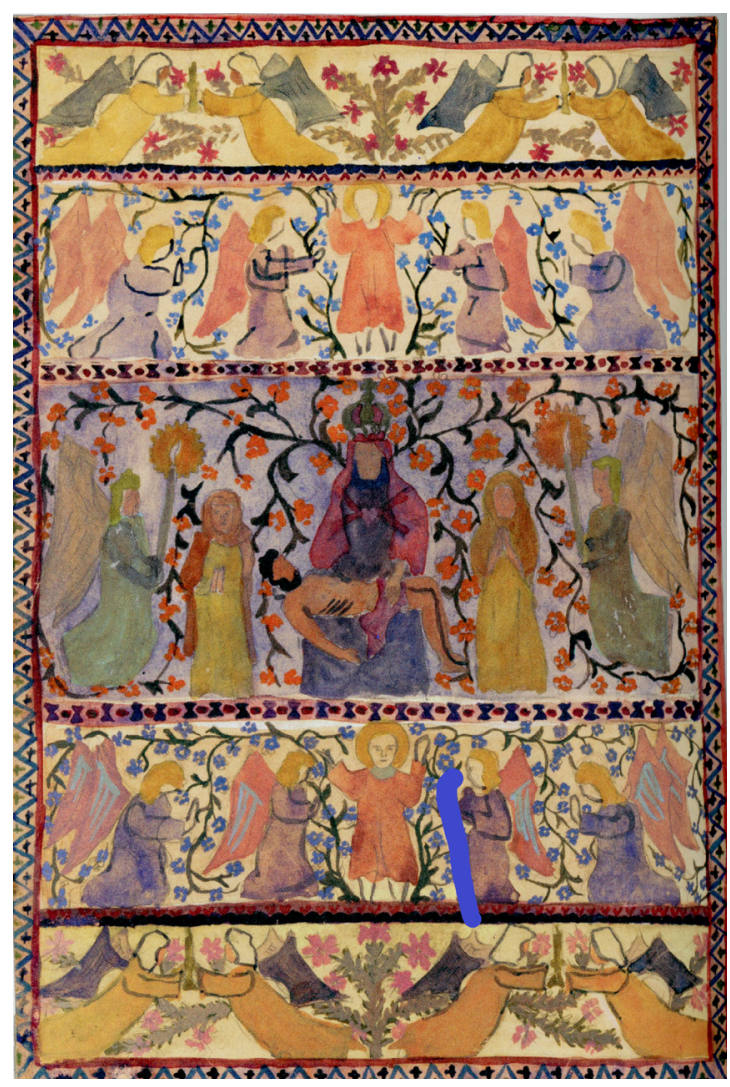

Fig. 3. Anonymous work. Pieta with Angels. 1940s. Watercolour, gouache on paper, $47.5 \times 33 \mathrm{~cm}$. Zenonas Varnauskas' Foundation, Kaunas, Lithuania
I was dismissed together with the others [...]. The accusations were of rather general nature ('formalist') and other, more serious ones, which they didn't disclose, but for which I might have ended up in very distant places" ${ }^{24}$ Later, Kairiūkštis managed to defend himself to a certain extent, and the wording of his dismissal was softened to "voluntary resignation".25 At that time, calling an artist a formalist equalled proclaiming him "an enemy of the people". The set designer Liudas Truikys would often receive such accusations. ${ }^{26}$ Unlike other teachers, he never attempted to adapt himself to the requirements of the Soviet system. At the institute he was constantly harassed by party functionaries about the specific trend of his work and the fact that he never spoke publicly about his worldview, never attended ideological meetings and refused to understand that art was at this time an ideological weapon. Truikys had a unique perception of the synthesis of art and music based on the rhythm of visual forms and the search for musicality. His inspiration was ancient Egyptian art and Oriental culture. Students had to be creative to fulfil Truikys' visions - for example, to combine the artistic principles of Oriental carpets, a horizontally striped composition typical of ancient Egyptian murals, and elements of Lithuanian folk art in their compositions. (Fig. 3) This original "Oriental" tradition lingered in the works of Lithuanian textile artists, though Truikys was dismissed in 1949. ${ }^{27}$

\section{STUDENTS: THE FAILURE TO MASTER THE CODE OF THE "NEW CULTURE"}

In the summer of 1947, eight students made it to the last year of studies at the Kaunas Institute of Applied and Decorative Art. The subjects of their graduation works were imposed on them. The basic requirement was to express the victory and optimism of Soviet life. The records of state examinations ${ }^{28}$ show that the titles of graduation works were strictly ideological: a panel The Victorious March of the Red Army, a painting The Battle of the Lithuanian Red Flag Klaipeda Division at Šiauliai, a ceramic vase The Red Ammunition Train, a sculptural high relief Assault, and a woven carpet Construction.

Let us take a look at one of the graduation works and the process of defending it. In July 1947, the student 
Zenonas Varnauskas defended his graduation work - the woven carpet Construction. ${ }^{29}$ (Fig. 4) He presented to the board a project in colour and drawings of the work. The minutes of the defending process show that its participants, rather than making statements, asked short questions and were rather tense. Yet, another obvious thing is that the discourse was matter-of-fact, the approach of the board was professional, and the artistic views had apparently come from the prewar Kaunas School of Art. A reviewer of the work, printmaker Mečislovas Bulaka, also noted the following positive features of the graduation work: the planar character of the composition, stylisation based on folk-style realism, richness of forms, and the element of colour and rhythm. ${ }^{30}$ Such features are attributed to modernist thinking.

Varnauskas's carpet Construction is a rather decorative planar composition with human figures. They are arranged in stripes and rhythmically, like in Egyptian reliefs, and are moving in opposite directions.

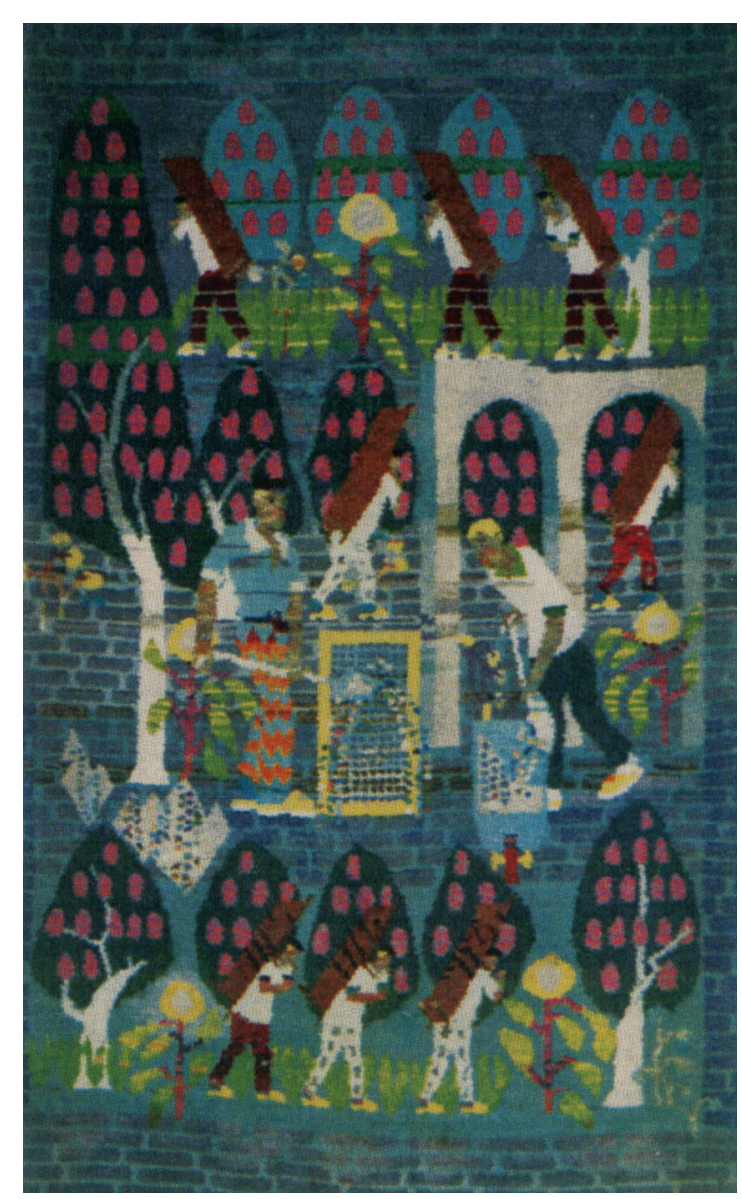

Fig. 4. Zenonas Varnauskas. Construction. 1947. Diploma work, tutor Liudas Truikys. Wool, weaving technique. Vilnius Academy of Arts, Department of Textiles
The repetitive motif of an arch was intended to symbolise the scale of construction or reconstruction. In the opinion of his academic supervisor Truikys, this candidate was "one of the talented students who proved his abilities not only in the execution of his graduation work, but also in graphic art and painting." ${ }^{31}$ Truikys assessed this graduation work from the modernist viewpoint. He emphasised that the student's compositions "speak a uniform language of form, rhythm and colours". ${ }^{32}$ Having noted minor technical shortcomings, the academic supervisor blamed them on the difficult work conditions: the institute did not have dyeing facilities and the fabric was received at the last moment, therefore weavers had to be found to weave the carpet manually, and they digressed from the drawing sketch excellently prepared by the student. ${ }^{33}$ The student Varnauskas's answers to the board's questions were fluent and not in the least politicised. He mentioned that his goals were retaining the planarity and rhythmicity characteristic of carpets (Truikys's school) and realism, though the latter was not there. Varnauskas' graduation work was given a "good" mark.

\section{ANNIHILATION OF THE INSTITUTION}

In the postwar period, the Institute of Applied and Decorative Art in fact continued the traditions of modernist art of the Kaunas School of Art. From the perspective of Soviet art functionaries, from 1940 the institute was considered an apolitical, modernist and formalist school, and the quality of studies was repeatedly appraised as unsatisfactory. The fact that there were no party activists in the institute, even though before the war there were quite many leftist artists in Lithuania, did not go unnoticed by the hegemon. ${ }^{34}$

In the spring of 1951, a routine inspection of the course of studies was implemented at the institute. Art functionaries stated that Socialist Realism had not become the basic method of the teachers' and students' work. ${ }^{35}$ This conclusion meant the final verdict for the Kaunas Institute: by a decree of the Council of Ministers of the USSR, it was closed. ${ }^{36}$ The new institute in Vilnius was given the name of the State Art Institute of the Lithuanian SSR. Thus, the plan of the Soviet authorities to destroy the 
national art school was implemented in ten years. In the Soviet narrative, it was called reorganisation of art studies in Lithuania and the merging of the Kaunas and Vilnius art institutes on the Vilnius base. Teaching facilities for the studies of applied art in Vilnius were not adequate. The premises of a former monastery were allotted for that purpose they were dark and cold. Textile artists did not have enough weaving looms, and ceramic artists needed kilns and laboratories for experiments. There was also a lack of professors, as some of them did not agree to move to Vilnius, and others were dismissed for having been among the founders of the Institute of Applied Art. Young teachers Sofija Veiveryte, Juozas Balčikonis and others started to work at the Institute of Applied Art.

\section{CONCLUSIONS}

In the period of Stalinism, when the authorities took all efforts to implement a political, social and cultural transformation, two parallel worlds seemed to have existed at the Kaunas Institute. The majority of teachers belonged to one of them, while art functionaries and several teachers were part of the other.

The teachers and students understood obligatory requirements and accepted the forced themes, but none of them tried to master the code of the imposed culture. Besides, they did not understand it, as their own teachers had been trained in the spirit of modernism or neo-traditionalism. Neither teachers nor students had the skills of naturalist representation for expressing socialist content. The teachers did not make students blindly follow Socialist Realism.

Students made minimal attempts to adapt to the requirements of propaganda art but, for example, they eagerly yielded to the influence of such teachers as the "mystic" Truikys. They realised that Truikys's ideas to combine the elements of Lithuanian folk art and the Oriental tradition of composition in a textile work might produce interesting results.

The majority of teachers tried to manoeuvre - they neither opposed the political hegemon nor collaborated with it. As has been shown in this text, a minority yielded to the Soviet rules while the majority pretended to be loyal, and some individuals tried to ignore the system.

One can state that the annihilation of the Kaunas Institute was a forced administrative act. The art school, though subjected to suppression and destruction, continued to exist, as young teachers who finished their studies at the Kaunas Institute and were taught by alumni of the Kaunas School of Art and European schools, began to work in Vilnius.

\section{References}

Anušauskas, Arvydas, Jonas Banionis ir Dalia Kuodytè. Lietuva 1940-1990: okupuotos Lietuvos istorija [Lithuania 1940-1990: The History of the Occupied Lithuania]. Vilnius: Lietuvos gyventojų genocido ir rezistencijos tyrimų centras, 2007.

Aschcroft, Bill. Key Concepts in Post-Colonial Studies. London-New York: Routledge, 1998.

Bagušauskas, Juozapas Romualdas, Arūnas Streikus, eds. Lietuvos kultūra sovietinès ideologijos nelaisveje 19401990 [Lithuanian Culture in the Grip of Soviet Ideology 1940-1990]. Vilnius: Lietuvos gyventojų genocido ir rezistencijos tyrimo centras, 2005.

Brogienè, Roma, ed. Vytautas Kairiūkštis. Straipsniai, paskaitos, dokumentai, laiškai, amžininku prisiminimai [Vytautas Kairiūkštis. Articles, Lectures, Documents, Letters, Contemporaries' Memoirs]. Vilnius: Vaga, 1989, 383.

Groys, Boris. The Total Art of Stalinism. Avant-Garde, Aesthetic Dictatorship, and Beyond. London-New York: Verso, 2011.

Jankevičiūte, Giedrè. Po raudonaja žvaigžde/Under the Red Star. Vilnius: Lietuvos kultūros tyrimų institutas, 2011.

Jankevičiūtè, Giedrè ir Rasa Žukienė, eds. The Art of Identity and Memory. Toward a cultural history of the two world wars in Lithuania. Boston: Academic Studies Press, 2016.

Kairiūkštis, Vytautas. "Kauno taikomosios ir dekoratyvinès dailès instituto studentų darbų paroda" [The Exhibition of Students' Works of the Kaunas Institute of Applied and Decorative Art]. In Tarybu Lietuva, 191 (1946): 3-4.

Lempertienè, Larisa, Jurgita Šiaučiūnaitè-Verbickienè, eds. Žydai Lietuvoje. Istorija, kultūra, paveldas [Jews in Lithuania. History, Culture, Heritage]. Vilnius: R. Paknio leidykla, 2009.

Mulevičiūtè, Jolita. "Apie tikrovès ribas ir dailès santykị su ideologija" [On the Limits of Reality and the Relation of Art and Ideology]. In Kultūros barai, 4 (2010): 36-45.

Natalevičienè, Lijana. "XX a. Lietuvos tekstilë" [Twentieth-Century Lithuanian Textile]. In Bogdanienè Egle Ganda, ed., Absoliuti tekstile. Nuo ištaku iki XXI amžiaus [Absolute Textile. From the Beginnings to 
the $21^{\text {st }}$ Century]. Vilnius: Vilniaus dailes akademijos leidykla, 2016, 109-135.

Piotrowski, Piotr. In the Shadow of Jalta: Art and AvantGarde in Eastern Europe, 1945-1989. London: Reaction Books, 2009.

Poklewski, Józef. Polskie życie artystyczne $w$ międzywojennym Wilnie. Toruń: Wydawnictwo Uniwersytetu Mikołaja Kopernika, 1994.

\section{Notes}

1 Bill Aschcroft, Key Concepts in Post-Colonial Studies (London-New York: Routledge, 1998), 215.

2 Giedrè Jankevičiūte, Rasa Žukienè, ed., The Art of Identity and Memory. Toward a cultural history of the two world wars in Lithuania (Boston: Academic Studies Press, 2016); Giedrè Jankevičiūtè, Po raudonaja žvaigžde/Under the Red Star (Vilnius: Lietuvos kultūros tyrimų institutas, 2011); Lijana Natalevičienė, "XX a. Lietuvos tekstilè" [Twentieth-Century Lithuanian Textile], in Absoliuti tekstile. Nuo ištaku iki XXI amžiaus [Absolute Textile. From the Beginnings to the $21^{\text {st }}$ Century] 109-135, Bogdaniene Eglè Ganda, ed. (Vilnius: Vilniaus dailès akademijos leidykla, 2016); Boris Groys, The Total Art of Stalinism. Avant-Garde, Aesthetic Dictatorship, and Beyond. (London-New York: Verso, 2011); Piotr Piotrowski, In the Shadow of Jalta: Art and Avant-Garde in Eastern Europe, 1945-1989 (London: Reaction Books, 2009).

3 Jolita Mulevičiūtè, "Apie tikrovès ribas ir dailès santykị su ideologija" [On the Limits of Reality and the Relation of Art and Ideology], Kultūros barai 4 (2010), 36-37.

4 The Kaunas Art School operated from 1922 to 1940. In 1940, its name was changed twice.

5 The new law on art schools was adopted on 15 May 1940.

6 After the World war II, name changes continued. The Vilnius Academy of Arts became the Vilnius State Art Institute. The Kaunas Institute of Applied Art was renamed as the Kaunas State Institute of Applied and Decorative Art according to the Soviet standards. In 1950, higher art studies were abolished in Kaunas.

7 Guidelines of the Council of People's Commissars of the Lithuanian SSR. 18 March 1941. LLMA (Lithuanian Literature and Art Archives, Vilnius), f. 61, ap. 2, b. 9, 1. 69 .

8 Leiba Miler's enrolment application. He asserted that "under the former regime it was simply impossible for me, as a Jew, to enter an art school". 26 September 1940. LLMA (Lithuanian Literature and Art Archives, Vilnius), f. 61, ap. 2, b. 9, 1. 26.

9 In 1922-1940, approximately twenty artists of Jewish descent studied at the Kaunas Art School. For more see: Larisa Lempertiené, Jurgita Šiaučiūnaitè-Verbickienė, eds. Žydai Lietuvoje. Istorija, kultūra, paveldas [Jews in Lithuania. History, Culture, Heritage], (Vilnius, 2009), 247.

10 Order 2 juni 1941. LLMA (Lithuanian Literature and Art Archives, Vilnius) LLAA, f. 61, ap. 2, b. 1, 1. 2.

11 The date of this ideological meeting was chosen not by accident. February 16 is the day of Independence of Lithuania.
12 The Pledge. 15 February 1941. LLMA (Lithuanian Literature and Art Archives, Vilnius), f. 61, ap. 2, b. 9, 1. 49. 13 The Pledge. 15 February 1941. LLMA (Lithuanian Literature and Art Archives, Vilnius), f. 61, ap. 2, b. 9, 1. 49. 14 Order of director Liudvikas Strolis of 20 March 1941. LLMA (Lithuanian Literature and Art Archives, Vilnius), f. 61 , ap. 2, b. 9, 1. 69 .

15 In the spring of 1943, the Nazi authorities closed all schools of higher education, as Lithuanian students refused to join the Nazi army.

16 In 1944, circa 60 thousand residents of Lithuania retreated to the West. Approximately 80 members of the Lithuanian Artists' Union emigrated. In: Arvydas Anušauskas, Jonas Banionis, Dalia Kuodyte. Lietuva 19401990: okupuotos Lietuvos istorija [Lithuania 1940-1990: The History of the Occupied Lithuania] (Vilnius, 2007), 367.

17 Boris Groys. The Total Art of Stalinism. Avant-Garde, Aesthetic Dictatorship, and Beyond (London-New York, 2011), 8-9.

18 Lecture notes of Rimtas Kalpokas. LLMA (Lithuanian Literature and Art Archives, Vilnius), f. 62, ap. 1, b. 1, 1. 68 19 Józef Poklewski. Polskie życie artystyczne w międzywojennym Wilnie (Toruń, 1994).

20 Kairiūkštis Vytautas. Attending the autumn art exhibition. LLAA (Lithuanian Literature and Art Archives, Vilnius), f. 397, ap. 2, b. 304, 1. 10.

21 Vytautas Kairiūkštis, "Kauno taikomosios ir dekoratyvinès dailès instituto studentų darbų paroda" [The Exhibition of Students' Works of the Kaunas Institute of Applied and Decorative Art], Tarybu Lietuva 191 (1946), 3-4.

22 In 1920-1921, Kairiūkštis studied at the Higher Art and Technical Studios (VCHUTEMAS) in Moscow under Pavel Kuznetsov.

23 Order No 32 of 21 July 1950. LLAA (Lithuanian Literature and Art Archives, Vilnius), f. 62, ap. 1, b. 61, 1. 49.

24 Vytautas Kairiūkštis's letter to Nadezhda Speranskaya. Kaunas, 20 January 1951. Quoted from the book: Roma Brogienè, Vytautas Kairiūkštis. Straipsniai, paskaitos, dokumentai, laiškai, amžininku prisiminimai [Vytautas Kairiūkštis. Articles, Lectures, Documents, Letters, Contemporaries' Memoirs] (Vilnius, 1989), 383.

25 Order No 35 of 21 August 1950. LLMA (Lithuanian Literature and Art Archives, Vilnius, orig. Lietuvos literatūros ir meno archyvas, Vilnius, Lietuva), f. 62, ap. 1, b. 61, 1. 52 .

26 Liudas Truikys studied at the private studio of professor Paul Colin in Paris (1934-1935), and took an interest in stage equipment in French and German theatres. In 1944-1947, he led the Department of Theatre Scenery, and taught the subjects of set design and textile composition at the Kaunas Applied and Decorative Art Institute.

27 Liudas Truikys was dismissed in 1949. LLMA (Lithuanian Literature and Art Archives, Vilnius), f. 62, ap. 3, b. $181,1.60$, b. $172,1.49$.

28 Minutes of the sessions of the state examining board. LLAA (Lithuanian Literature and Art Archives, Vilnius), f. 62 , ap. 4, b. $24,1.9$.

29 Ibid., l. 9.

30 Ibid., 1. 10.

31 Ibid., 1. 10

32 Ibid., l. 10.

33 Ibid., 1. 10-11. 
- 34 Already before the Soviet occupation, printmakers Vytautas Jurkūnas, Jonas Kuzminskis, painters Liuda Vaineikytė, Vytautas Mackevičius and Irena Trečiokaitė-Žebenkienè were famous for their leftist views in Lithuania. After the Second World War, they formed the core of local Communists and became a pillar of Moscow in the artistic community.
35 Decree of 21 April 1951, after conducting an inspection of work of the Kaunas Institute of Applied and Decorative Art. LLMA (Lithuanian Literature and Art Archives, Vilnius) f. 289, ap. 1, b. 12, 1. 96.

36 Decree No. 649 of the Council of Ministers of the USSR of 5 August 1951 on the merging of the Kaunas and Vilnius Art Institutes.

Rasa ŽUKIENE்

Vytauto Didžiojo universitetas, Kaunas, Lietuva

\section{MENO MOKYMAS GALIOS SANTYKIŲ KONTEKSTE: KAUNO TAIKOMOSIOS IR DEKORATYVINĖS DAILĖS INSTITUTO VEIKLA IR UŽDARYMAS (1940-1951)}

\section{Santrauka}

Šio straipsnio tikslas - analizuoti politinės galios ir ideologijų itaką meno studijoms Lietuvoje ir dailininkų pedagogų kūrybai 1940-1953 m. periodu. Remiamasi meno istorikams mažai žinomu Kauno taikomosios ir dekoratyvinès dailess instituto veiklos ir jo prievartinio uždarymo 1951 metais atveju. Po II pasaulinio karo šis institutas faktiškai buvo Kauno meno mokyklos (1922-1940) modernistinių meno tradicijų tęsèjas Lietuvoje. Kaip tik tai ir buvo jo sunaikinimo priežastis. Oficialiai sovietinių valdininkų kalbose tai buvo vadinama dailès studijų reorganizavimu ir perkèlimu ị LSSR sostinę Vilnių.

Po karo ị Lietuvą sugrįžusios sovietų valdžios primestas ideologinis turinys ir valdžios galia stipriai veikè meno studijų procesus. Tačiau Kauno taikomosios ir dekoratyvinès dailès institute pedagogai iš esmès vadovavosi prieškarinèmis, modernistinèmis nuostatomis, neprièmè sovietinių direktyvų arba žiūrèjo ị jas paviršutiniškai. Šiame straipsnyje parodoma, kaip politinè galia ir primestos ideologinès nuostatos koregavo dailès studijas ir kartais keité brandžių dailininkų kūrybą bei jų pasisakymus apie meną.

Straipsnyje keliamas klausimas apie prisitaikymo ir pasipriešinimo gyvenime ir kūryboje kainą ir atspalvius. Keliama mintis, kad meno institucijos sunaikinimas įmanomas, bet nę̨manoma staiga sunaikinti meninės mokyklos tradicijų. I šiuos ir kitus panašius klausimus bus bandoma atsakyti šiame tekste, remiantis archyviniais dokumentais ir keleto skirtingų kartų menininkų - Vytauto Kairiūkščio (1891-1961), Liudo Truikio (1904-1987), Zenono Varnausko (1923-2010) kūrybos pavyzdžiais.

Reikšminiai žodžiai: Kauno meno mokykla, Kauno taikomosios ir dekoratyvinès dailès institutas, II pasaulinis karas, tautinis modernizmas, socialistinis realizmas.

\section{Rasa ŽUKIENE்}

Rasa Žukienė $\mathrm{PhD}$ is an art historian and curator, professor in the Faculty of Arts in Vytautas Magnus University, Kaunas, Lithuania. She has published numerous articles, exhibition catalogues on Lithuanian art of the 20th century and several scientific monographs. Her research interests include the work of painter and composer Mikalojus Konstantinas Čiurlionis and its relationship with the work of other artists from around the world, Lithuanian modern art of the 20th century, and art by Lithuanian émigrés in the world. 